\title{
Teachers' Self-Reported Pedagogical Changes: Are We Preparing Teachers for Online STEM Education?
}

\author{
Hyun Jung Kang \\ University of Northern Colorado \\ Matthew Farber
University of Northern Colorado \\ Kimberly A. Mahovsky \\ University of Northern Colorado
}

At the onset of the COVID-19 pandemic in March 2020, K-5 teachers were forced to shift their teaching practices from in-person instruction to an emergency remote teaching (ERT) format. Using the TPACK framework (Koehler et al., 2014), this study explores how teachers' pedagogical practices for STEM instruction may have changed during and after ERT. The results indicate no significant differences in terms of direct instruction. Still, there were noticeable changes with collaborative learning and teachers' use of technological tools in STEM classrooms. Teachers' self-reporting of their pedagogical practices shift highlights the need for further professional development in the practical use of technological tools to meet current needs.

Keywords: COVID-19, educational technology, emergency remote teaching, online teaching, pandemic, STEM education, STEM pedagogy, teacher education, TPACK

\section{INTRODUCTION}

Compared to other disciplines (e.g., social studies, English language arts), science, technology, engineering, and mathematics (STEM) is a newer field of study with varying definitions that depend on context (Dare et al., 2019). Nadelson and Seifert (2017) define "integrated STEM" as being on a continuum or spectrum, a "seamless amalgamation of content and concepts from multiple STEM disciplines" (p. 221). Policymakers, educators, and researchers define STEM differently, and the term itself is "used loosely" in the literature (Dare et al., 2019, p. 1702).

As an interdisciplinary field, is there a "hub" where other disciplines are brought together? Should STEM education focus on engineering or science? In classrooms, STEM should integrate multiple disciplines and be more about hands-on application than the rote learning of theory (Breiner et al., 2012; English, 2016). However, in classrooms, one subject tends to be the dominant taught discipline (Honey et al., 2014). 
STEM education is a learning strategy intended to improve critical and creative thinking skills enabling students to face the challenges of the 21st-century (Zulirfan et al., 2020). Although exact definitions remain "elusive" in the literature (English, 2016, p. 221), for this paper, we used the definition from Tsupros et al. (2009), as it was the one stated in the state teaching standards where data were collected, and where participants taught. STEM education is defined as,

An interdisciplinary approach to learning where rigorous academic concepts are coupled with real-world lessons as students apply science, technology, engineering, and mathematics in context that make connections between school, community, work, and the global enterprise, enabling the development of STEM literacy and with it the ability to compete in the new economy. (Tsupros et al., 2009, p. 2)

The COVID-19 outbreaks in 2020 disrupted schooling, including in-person teaching in STEM classrooms. As the pandemic spread through the United States in spring 2020, most K-12 classrooms abruptly shifted to an online format. Emergency remote teaching (ERT) describes the "temporary shift of instructional delivery to an alternate delivery mode due to crisis circumstances" (Hodges et al., 2020, para. 13). ERT should, therefore, be differentiated from other models of distance learning, such as blended, hybrid, flipped, and mobile learning (Hodges et al., 2020; Marshall et al., 2020). During ERT, little to no time was afforded for teachers to plan synchronous or asynchronous instruction (Cavanaugh \& DeWeese, 2020; Hodges et al., 2020; Marshall et al., 2020).

The transition to ERT followed recommendations published on March 12, 2020 from the Centers for Disease Control and Prevention, as well as from state and local guidance (Marshall et al., 2020). The remote learning models that schools adopted to follow this guidance varied: some used completely digital tools, such as video conferencing software (e.g., Zoom) and learning management systems (e.g., Google Classroom); other schools provided students with packets of worksheets and written assignments (Marshall et al., 2020). Because of ERT, some students lacked access to course materials necessary to facilitate STEM instruction, and were left at a disadvantage (Santanu, 2020).

In typical circumstances, distance learning can take advantage of the affordances of online tools that can promote student-centered, experiential learning (Hodges et al., 2020). For instance, students can learn STEM online collaboratively (e.g., recording data on shared Google Sheets), or self-pace with personalized lessons (i.e., video-based STEM lessons). ERT, sometimes called "pandemic pedagogy" (Milman, 2020, para. 1) differs in that the change in teaching delivery was based on a rapid scramble to keep a sense of educational continuity with students. The move to ERT had other unique challenges, including students who suddenly found themselves socially and physically isolated from their peers.

The public health measures that followed the COVID-19 pandemic may have had consequential effects on a teacher's ability to support student engagement, as well (Code et al., 2020). From a social aspect, education in 2020 became disconnected from student life, and parents have been sitting alongside students to guide and support them with their progress (Black et al., 2020; Stefanile, 2020). The pandemic may have also revealed a lack of curriculum prescribed competencies, equity, and access to learning for all eroded and repressed learning of unmotivated students (Code et al., 2020; Cahapay, 2020).

This study sought to understand the extent to which ERT in K-5 classrooms affected teachers' teaching pedagogy in STEM instruction. The particular focus was placed on STEM pedagogy with K-5 classrooms for two reasons. First, teaching STEM concepts are critical to prepare students with 21 st-century skills (Kelly \& Knowles, 2016; Schmidt \& Fulton, 2016). Second, the emphasis of STEM at elementary school level improves students' motivation and competencies in the STEM related field (Bartholomew, Strimel, Zhang \& Homan, 2018).

\section{STEM EDUCATION DURING EMERGENCY REMOTE TEACHING}

When teachers have time to prepare to teach online, they should consider modality, pacing, studentinstructor ratio, pedagogy, instructor role online, student role online, online communication synchrony, the 
role of online assessments, and source of feedback in coursework (Means et al., 2014). Typically, some or all these dimensions are planned from the onset, from instructors who are trained, students who are prepared, and school infrastructure that is set up (Cavanaugh \& DeWeese, 2020; Hodges et al., 2020). However, ERT, by definition, was an unplanned approach to online learning, a response to COVID-19 and its immediate and unexpected disruption to in-person instruction.

Research on teachers' prior experiences with technology are essential when trying to understand the implications of later shifts to ERT. In a study of K12 teachers surveyed from April through May of 2020 $(n=325)$, Trust and Whalen (2020) found that those who had used educational technology before the shift had an easier transition than those who did not. Challenges reported by participants included feelings of being overwhelmed (61\%) and lack of knowledge about online learning tools (44\%) (Trust \& Whalen, 2020). Participants also reported concerns over students' lack of internet availability and other stressors, such as their own personal health and well-being (Trust \& Whalen, 2020). Teachers who self-reported proficiency in educational technology, and those new to these tools, professed to be "building the plane while flying it" (Trust \& Whalen, 2020, p. 193).

Marshall et al. (2020) surveyed teachers $(n=328)$ from March through April 2020. Nearly all participants (92.4\%) responded that they lacked formal training on online instruction of any kind, ERT, or planned distance learning methods (Marshall et al., 2020). About half (49\%) of the teachers surveyed indicated some prior degree of familiarity with some tools, like Microsoft Teams and Google Classroom. They felt somewhat prepared to teach online (Marshall et al., 2020). In addition to technological proficiency, Marshall et al. (2020) elucidated other challenges facing K-12 teachers during ERT. Issues self-reported included low student engagement, problems relating to keeping children accountable, chronic absenteeism, and some internet connection problems (Marshall et al., 2020).

Since the beginning of the 21st-century, computer-based learning has been used to support STEM classrooms to develop student-centered and collaborative learning, access data, and promote interdisciplinary STEM skills and strategies (Holmlund, Lesseig, \& Slavit, 2018; Code, Ralph, \& Forde, 2020). Nonetheless, STEM learning during ERT presented obstacles for educators (Zulirfan et al., 2020; Korkmaz \& Toraman, 2020).

Educators can emphasize real-life problem-solving skills by modifying the curriculum to be more effective by promoting educators' creative thinking skills (Korkmaz \& Toraman, 2020). However, social distancing requirements during ERT constrain group work approaches that require interactions with close physical contacts must be modified, reduced, or eliminated altogether from pedagogical options (Cahapay, 2020; Santanu, 2020; Zulirfan et al., 2020: Stefanile, 2020).

According to Freire (2000), "to teach is not to transfer contents to anyone, just as to learn is not to memorize the outline of some content that has been transferred by the teacher, but to create the possibilities for the production or construction of knowledge." Zulirfan et al. (2020) asserts the pedagogy most often carried out in teaching science during ERT was solving science questions assigned to them by the teacher and a substantial increase in reading and summarizing content in their science textbooks. In fact, students reported seldom being given assignments to do science works, a project, or observing a scientific wonder in their environment (Zulirfan et al., 2020). This pedagogical practice is not surprising due to the sudden shift to ERT. Educators had to prepare and implement online learning, suddenly making it necessary to give assignments to read and summarize subject matter making it more efficient to prepare and assign online (Zulirfan et al., 2020; Van Nuland et al., 2020).

Research suggests pedagogy aligned with STEM Standards should adapt to constant shifts in today's interconnected world. Colorado STEM Standards and Instruction (2020), where this study took place, addresses that inquiry, critical thinking, reasoning, and collaboration are core pedagogy in STEM classrooms. Commonalities of STEM Standards reveal some core aspects of STEM pedagogy in classrooms.

STEM classrooms can emphasize student-centered teaching where children actively develop problemsolving skills (Breiner et al., 2012; English, 2016). In elementary STEM instruction, inquiry-based learning can facilitate students' problem-solving abilities through scientific investigations, which include question, hypothesize, design, data collection, conclusion, and justification for the proposed explanation (Liang \& Richardson, 2009; NRC 2000; Plonczak, 2010, Valma et al., 2009). 
Other areas of STEM education research focus on the importance of problem-solving and collaboration in STEM classrooms. Hwang and Lai (2007) suggest that interactive problem-solving enhances students' capabilities of solving real-world problems. Interactive problem-solving also provides opportunities for open-ended questions, critical thinking, and the use of multiple pedagogical strategies (Baxter et al., 2001; NCTM 2000; Riordan \& Noyce, 2001).

In K-5 classrooms, social interaction and collaboration are also critical, as these dynamics enable students to construct their STEM knowledge (Wood, 1993) and improve math and science cognitive skills (Satchwell \& Leopp, 2002). In this study, how STEM standards are aligned in classrooms and how they possibly changed during the COVID-19 pandemic were explored.

The previous research addresses the pedagogical focus of STEM standards and the role of TPACK in driving STEM instructions in the classrooms. It also addresses the challenges of the abrupt implementation of ERT in STEM classrooms. However, there is a deficit in research that reports the relationship between STEM pedagogy and ERT in the classrooms because COVID-19 was an unexpected disruption.

This study expands on previous research by investigating its relationships. The overarching goal of this study is to explore how STEM Standards-based teaching pedagogy is affected by ERT. The following research questions guided our research:

a. To what extent does ERT in a global pandemic affect STEM pedagogical practices in elementary (K-5) classrooms?

b. How do pedagogical practices for STEM teaching change or adapt due to the alternate format of teaching experiences in K-5 classrooms instituted by COVID-19?

\section{CONCEPTUAL FRAMEWORK}

The technological pedagogical content knowledge (TPACK) framework (Koehler et al., 2014) served as this study's conceptual framework. A conceptual framework bridges "paradigms that explain the research issue and the actual practice of investigating that issue" (Bloomberg \& Volpe, 2016, p. 128).

The TPACK framework is a dynamic model designed to help teachers think about how their content and pedagogical knowledge domains intersect with educational technology tools (Koehler et al., 2014; Koehler \& Mishra, 2009; Mishra \& Koehler, 2006). It was adapted from Shulman's (1987) PCK knowledge base framework, which considered the intersection of pedagogical knowledge (PK) with content knowledge (CK) as ideal for student learning. PK, which describes the methods used to teach CK, includes instructional strategies, teaching methods, and assessments. PK includes varying teaching approaches, from projectbased learning to game-based learning to direct instruction (DI). CK pertains to teachers' expertise within their content discipline, including the facts, theories, and concepts that make up their curricular areas of teaching (Shulman, 1987).

Mishra and Koehler (2006) built on the work of Shulman (1987) to consider how learning can be supported with technological tools or technological knowledge (TK). TK in TPACK describes teachers' understanding of the tools that can best support learning. As with the relationship PK and CK share, Mishra and Koehler (2006) proposed that technological knowledge (TK) is bilateral, supporting both PK and CK components.

Sometimes written as TPCK, TPACK accounts for classrooms' unique contexts, which may differ widely (e.g., Koehler et al., 2014). For instance, teacher training, device or internet access, and availability of curricular resources (i.e., textbooks, lab equipment) can be dependent on several factors, including the location of school and funding (Koehler et al., 2014).

In STEM classrooms, content standards drive CK, which should be aligned to the pedagogical approach teachers use to engage students. TK describes the array of hands-on, experiential tools available to students that support their learning. These may include digital simulations and games, curated websites featuring curricular content, and collaborative documentation tools (e.g., Google Slides), where students can record and share data. The TPACK framework enabled us to examine STEM learning implementation throughout

each of the three data collection phases. Teacher reflection on practice is a useful approach to understanding the connections between the three components reflected by the study participants (Koehler et al., 2017). 


\section{METHOD}

\section{Participants}

The study's target population was teachers in K-5 classrooms during Spring 2020 within the state of Colorado. The aforementioned definition of STEM education from Tsupros et al. (2009) is listed first by the Colorado Department of Education (CDE) on its Colorado's STEM Standards and Instruction website. As such, this definition preceded the first question in each round of administered surveys.

The participants were contacted through email addresses obtained from the school of teacher education from the authors' institution (also located in Colorado). Among the invited K-5 teachers, 24 teachers participated in Survey 1, and of these 24 teachers of the Survey 1, 14 teachers participated in Survey 2 in April through May 2020. Teachers were recruited through convenience sampling (Yin, 2009). The invitation for Survey 3 was sent to 14 teachers who completed both Surveys 1 and 2, and among 14 teachers, six teachers completed Survey 3. Thus, a total of six teachers completed all three stages of the survey for the study, and this study reports the results of these six teachers. Table 1 details the participating teachers.

TABLE 1

\section{BACKGROUND OF PARTICIPANTS}

\begin{tabular}{lcccccc}
\hline Name & Ashley & Emma & Jessica & Judy & Lauren & Francis \\
\hline Gender & $\mathrm{F}$ & $\mathrm{F}$ & $\mathrm{F}$ & $\mathrm{F}$ & $\mathrm{F}$ & $\mathrm{F}$ \\
\hline Year of teaching & $0-2$ & $0-2$ & $11+$ & $11+$ & $11+$ & $11+$ \\
& years & years & years & years & years & years \\
\hline School Type & Public & Title 1 & Public & Public & Public & Public \\
& K-5 & K-5 & K-5 & K-5 & K-5 & K-5 \\
\hline School Setting & Suburban & Rural & Suburban & Suburban & Urban & Rural \\
\hline STEM training & Compulsory & Compulsory & $\begin{array}{c}\text { Own } \\
\text { discretion }\end{array}$ & $\begin{array}{c}\text { Own } \\
\text { discretion }\end{array}$ & $\begin{array}{c}\text { Own } \\
\text { discretion }\end{array}$ & $\begin{array}{c}\text { Own discretion } \\
\text { discrion }\end{array}$ \\
\hline $\begin{array}{l}\text { Number of STEM } \\
\text { lesson per week }\end{array}$ & 5 & 5 & 4 & 5 & 1 & 1 \\
\hline Computer Use & daily & daily & daily & daily & daily & daily \\
\hline
\end{tabular}

\section{Data Collection and the Process}

An online survey was administered via Qualtrics, and it was distributed three times between April and November of 2020. The purpose of asking the same survey questions multiple times was to assess how pedagogy might have possibly changed by COVID-19, impacting teaching face-to-face in schools.

To measure the change, we designed three phases of data collection based on the mode of instruction. Phase 1 is defined as the time before the COVID 19 pandemic when the classes typically met in person. These dates span from the start of the school year, August 2019, through March 12, 2020, the date when CDC and Colorado recommended that all schools move to ERT. Phase 2 is defined as after March 12th through the end of the academic school year, end of May. All schools, at this time in Colorado, were fully ERT. Phase 3 took place mid-October 2020 when districts self-determined the option for in-person classroom experiences.

Participants took Surveys 1 and 2 during April through May 2020. Survey 1 asked participants to think about their instruction retrospectively, focusing on pre-COVID-19 pedagogy from January through March. Survey 2 then asked identical questions, asking participants to focus on current pedagogical practices during COVID 19, April through May. Again, both Survey 1 and Survey 2 occurred at the onset of our study, in April through May 2020. Survey 3, again with identical questions, was conducted at the end of the study, in October through November 2020.

As we aimed to measure pedagogical changes when shifting to in-person teaching during Phase 3 where Survey 3 asked teachers to report their current mode of instruction from October through November 2020 
whether it was either 100\% remote learning or in-person teaching (hybrid or in-person). In-person teaching was defined as students being physically in classrooms at least once a week. Only those participants who reported conducting in-person instruction were directed to Survey 3.

\section{Survey Instrument}

We adopted and revised questions from Nistor et al. (2018), who conducted a large scale survey $(n=3,780)$ of STEM pedagogical practices across Europe published in the STEM Education Policies report (2018). As this project was designed to assess STEM instruction's current practice in secondary classrooms (e.g., pedagogical approach and types of learning materials), the published survey questions provided insight for our work.

The survey questions focused on pedagogical approaches and practices for STEM teaching and the use of technological tools during these STEM lessons. To measure the frequency of pedagogy implementation in this self-reported survey, a Likert-like scale ranging from 1-4 was utilized. One indicated "not at all," 2 was "very little," 3 meant "to some extent," and 4 indicated "a lot."

There were nine questions on the survey; questions 1 through 6 asked about the teacher's background such as years of teaching, school setting, school types, STEM training, number of STEM lessons per week and the use of computers in the lessons (see the Table 1 above). Question 7 focused on the type of STEM teaching pedagogy, Question 8 was about aspects of pedagogical practices when teaching STEM, and question 9 pinpointed the technological tools that teachers used in the classrooms. Subitems were measured under Questions 7, 8, 9, and each item's definition was described in the survey questionnaires enabling respondents to have a common understanding of each subitem. Table 2 represents the questions and subitems for Question 7. The subitems within Questions 8 and 9 are provided in the results section.

\section{TABLE 2}

\section{SAMPLE SURVEY QUESTION OF QUESTION 7}

\begin{tabular}{l|l|l|l|l}
\hline $\begin{array}{l}\text { Q7. What approach to instruction are you using in your } \\
\text { classroom for STEM teaching and how much? }\end{array}$ & $\begin{array}{c}\text { Not at all } \\
\text { (1) }\end{array}$ & $\begin{array}{c}\text { Very } \\
\text { little (2) }\end{array}$ & $\begin{array}{c}\text { To some } \\
\text { extent (3) }\end{array}$ & $\begin{array}{c}\text { A lot } \\
\text { (4) }\end{array}$ \\
\hline $\begin{array}{l}\text { 1. Traditional direction instruction (lessons are focused } \\
\text { on the delivery of content by the teacher and the } \\
\text { acquisition of content knowledge by the students) }\end{array}$ & & & & \\
\hline $\begin{array}{l}\text { 2. Project-based Science Education (students design } \\
\text { and conduct their own scientific investigations) }\end{array}$ & & & & \\
\hline $\begin{array}{l}\text { 3. Problem-based approach (students are engaged in } \\
\text { learning through the investigation of real-world } \\
\text { challenges and problems) }\end{array}$ & & & & \\
\hline $\begin{array}{l}\text { 4. Inquiry-based Science Education (students design } \\
\text { and conduct their own scientific investigations) }\end{array}$ & & & & \\
\hline $\begin{array}{l}\text { 5. Cooperative learning (students are involved in joint } \\
\text { intellectual efforts with their peers or with their } \\
\text { teachers and peers) }\end{array}$ & & & & \\
\hline $\begin{array}{l}\text { 6. Peer teaching (students are provided with } \\
\text { opportunities to teach other students) }\end{array}$ & & & & \\
\hline $\begin{array}{l}\text { 7. Flipped classroom (students gain the first exposure } \\
\text { to new material outside of class and then use classroom } \\
\text { time to discuss, challenge and apply ideas or }\end{array}$ & & & & \\
knowledge). & & & & \\
\hline $\begin{array}{l}\text { 8. Game-based learning (using games to promote } \\
\text { critical thinking and simulation) }\end{array}$ & & & & \\
\hline 9. Constructivist learning (learning by doing) & & & & \\
\hline
\end{tabular}




\section{Analysis of Surveys}

The surveys were analyzed drawing on time-series analysis (Yin, 2009) as we surveyed multiple times. The data were collected from six teachers who completed the identical survey at three different phases. The time-series analysis allowed us to trace the changes over time, especially under the specific event of COVID-19. First, the authors calculated the mean of sub-items within Questions 7, 8, 9 from Survey 1 to explore trends of teachers' instructional strategies in STEM teaching prior to ERT. We interpreted that the higher mean, close to 4 ("a lot" category), to indicate more frequent use of particular teaching methods or technological tools. The lower mean, close to 1 ("not at all"), demonstrated seldom use in a respondents' STEM teaching. For instance, when the mean number fell between $0-1$, we defined those teachers as rarely engaged with the corresponding teaching pedagogy, and a mean between 1-2 indicated the teacher engaged in the pedagogical approach a little bit. The mean number between 3-4 represented active engagement with that pedagogical method.

We then calculated the mean during ERT, Phase 2 (Survey 2), and compared those means to Phase 1 to measure the difference. We reported the mean and the difference using plus and minus signs. A difference with a plus sign $(+)$ represented the increased use of the particular teaching method, and the minus sign (-) indicated the decreased use of the corresponding STEM pedagogy. Because ERT was the most significant event that occurred during the research period, the authors reported the means and its comparison in chronological order of Phases 1, 2, 3.

\section{RESULTS}

We first illustrate the change of STEM teaching pedagogy over time in terms of the pedagogical approach (Question 7), pedagogical practices in STEM (Question 8), and the use of technological tools in STEM instruction (Question 9). We then identified how these changes appeared among the six participating teachers.

\section{Changes in Pedagogical Approaches and Practices in STEM Teaching}

Table 3 provides a summary of how the frequency of STEM pedagogical approaches changed over time during ERT.

TABLE 3

FREQUENCY OF STEM PEDAGOGICAL APPROACHES OVER 3 PHASES

\begin{tabular}{|c|c|c|c|c|c|}
\hline \multirow[b]{2}{*}{$\begin{array}{l}\text { Q7. What approach to instruction } \\
\text { are you using in your classroom for } \\
\text { STEM teaching and how much? }\end{array}$} & \multirow{2}{*}{$\begin{array}{c}\text { Phase 1 } \\
\text { Jan-Mar,12 } \\
2020 \\
\text { Mean }\end{array}$} & \multicolumn{2}{|c|}{$\begin{array}{c}\text { Phase } 2 \\
\text { Mar 13-May } 2020\end{array}$} & \multicolumn{2}{|c|}{$\begin{array}{c}\text { Phase } 3 \\
\text { Oct-Nov } 2020\end{array}$} \\
\hline & & Mean & $\begin{array}{l}\text { Change } \\
\text { between } \\
\text { P1 \& P2 }\end{array}$ & Mean & $\begin{array}{l}\text { Change } \\
\text { between } \\
\text { P2 \& P3 }\end{array}$ \\
\hline 1. Traditional Direct Instruction & 3.2 & 2.5 & -0.7 & 2.5 & 0 \\
\hline 2. Project Based Instruction & 3.0 & 2.2 & -0.8 & 2.5 & +0.3 \\
\hline 3. Problem Based Instruction & 3.3 & 2.7 & -0.6 & 2.8 & +0.1 \\
\hline 4. Inquiry Based Instruction & 2.8 & 2.0 & -0.8 & 2.2 & +0.2 \\
\hline 5. Cooperative Learning & 3.5 & 2.0 & -1.5 & 3.5 & +1.5 \\
\hline 6. Peer Teaching & 3.2 & 1.5 & -1.7 & 2.5 & +1.0 \\
\hline 7. Flipped Classroom & 1.8 & 1.8 & 0.0 & 2.0 & +0.2 \\
\hline 8. Game Based Learning & 2.7 & 2.2 & -0.5 & 2.7 & +0.5 \\
\hline 9. Constructivist Learning & 3.5 & 2.7 & -0.8 & 3.5 & +0.8 \\
\hline Average & 2.6 & 2.2 & -0.4 & 2.7 & +0.5 \\
\hline
\end{tabular}


First, the findings indicated that before ERT, among the nine pedagogical approaches, cooperative learning and constructivist learning were the most commonly used in STEM instruction with an average of 3.5 out of 4 , and problem-based instruction $(M=3.3)$ and traditional direct instruction $(M=3.2)$ follow. The survey also showed that the teachers did not use either flipped classroom $(\mathrm{M}=1.8)$ or game-based learning $(M=2.7)$ prior to ERT. Yet, as Phase 2 began, the trend changed. The trend showed that the engagement of almost every single category of STEM pedagogy decreased in general. It is noticeable that of the nine categories, cooperative learning and peer teaching dropped the most during ERT. When the instruction began to incorporate some face-to-face aspect during fall 2020, teachers reported that they used these pedagogical approaches more often than during ERT. However, the frequency level was not as high as before ERT during 100\% in-person instruction.

Table 4 reports the results of our analysis of participants' responses to Question 8. Question 8 assessed teachers' pedagogical practices while teaching STEM lessons, and examples of pedagogical practices were provided. The general trend seems similar to the responses of Question 7 above. All participants reported that ERT limited the STEM practices they used to use during face-to-face instruction, especially interaction among students. Items 4 and 5 revealed that students' group work and collaboration had dropped significantly during ERT. In the meantime, student's individual work increased (from mean 2.3 to 3.3) during ERT. Prior to ERT, the most common teaching strategy utilized was student discussion $(\mathrm{M}=3.7)$ during STEM lessons, but during ERT, it shifted to students working individually.

TABLE 4 CHANGES IN THE PEDAGOGICAL PRACTICES OVER 3 PHASES

\begin{tabular}{|c|c|c|c|c|c|}
\hline \multirow[b]{2}{*}{$\begin{array}{l}\text { Q8. To what extent do you use the } \\
\text { following aspects of teaching and learning } \\
\text { when teaching STEM? }\end{array}$} & \multirow{2}{*}{$\begin{array}{c}\text { Phase } 1 \\
\text { Jan-Mar } 12 \\
2020 \\
\text { Mean }\end{array}$} & \multicolumn{2}{|c|}{$\begin{array}{c}\text { Phase } 2 \\
\text { Mar 13-May } 2020\end{array}$} & \multicolumn{2}{|c|}{$\begin{array}{c}\text { Phase } 3 \\
\text { Oct-Nov } 2020\end{array}$} \\
\hline & & Mean & $\begin{array}{l}\text { Change } \\
\text { between } \\
\text { P1 \& P2 }\end{array}$ & Mean & $\begin{array}{l}\text { Change } \\
\text { between } \\
\text { P2\& P3 }\end{array}$ \\
\hline 1. Student work alone at their own pace & 2.3 & 3.3 & +1 & 2.8 & -0.5 \\
\hline 2. Students discuss ideas with others & 3.7 & 2.8 & -0.9 & 3.7 & +0.9 \\
\hline $\begin{array}{l}\text { 3. Student make decisions about how they } \\
\text { learn (Inquiry -based learning) }\end{array}$ & 2.8 & 2.3 & -0.5 & 2.5 & +0.2 \\
\hline $\begin{array}{l}\text { 4. Students work in groups, with well- } \\
\text { defined tasks }\end{array}$ & 3.2 & 1.8 & -1.4 & 2.7 & +0.9 \\
\hline 5. Students work collaboratively & 3.5 & 2.2 & -1.3 & 2.8 & +0.6 \\
\hline $\begin{array}{l}\text { 6. I use math manipulatives to support } \\
\text { student learning }\end{array}$ & 2.7 & 2.7 & 0 & 3.3 & +0.6 \\
\hline $\begin{array}{l}\text { 7. I invite other STEM teachers of different } \\
\text { disciplines }\end{array}$ & 1.7 & 1.3 & -0.4 & 1.5 & +0.2 \\
\hline $\begin{array}{l}\text { 8. I give feedback to my students during } \\
\text { learning activity }\end{array}$ & 3.2 & 2.5 & -0.7 & 3.3 & +0.8 \\
\hline Average & 2.9 & 2.4 & -0.5 & 2.8 & +0.4 \\
\hline
\end{tabular}

\section{Technological Tools and STEM Instruction}

Compared to the average change of frequency of STEM pedagogical approaches (-0.4) and pedagogical practices (-0.5), the change in usage of technological tools in STEM instruction seemed relatively smaller. In terms of technological tools, it appeared that the nature of online teaching and learning during ERT brought about decreased use of paper-based materials significantly and boosted the use of word processors. Table 5 illustrates the use of advanced STEM-related tools, e.g., robots, STEM-specific software, and online collaborative tools, was low (close to the "not at all" category) prior to ERT and remained at this level during ERT. One noticeable aspect was online collaborative tools' operation increased significantly 
from the "very little" category prior to ERT $(M=1.7)$ to the "a lot" category $(M=3.5)$ when the mode of delivery shifted to an in-person structure (see Table 5).

\section{TABLE 5}

\section{CHANGES IN TECHNOLOGICAL TOOLS DURING STEM INSTRUCTION OVER 3 PHASES}

\begin{tabular}{l|c|c|c|c|c}
\hline & $\begin{array}{c}\text { Phase 1 } \\
\text { Jan-Mar 12, } \\
2020\end{array}$ & \multicolumn{2}{|c|}{$\begin{array}{c}\text { Phase 2 } \\
\text { Mar 13-May 2020 }\end{array}$} & \multicolumn{2}{|c}{$\begin{array}{c}\text { Phase 3 } \\
\text { Oct-Nov 2020 }\end{array}$} \\
\hline $\begin{array}{l}\text { Q9. Which learning resources/materials are } \\
\text { you using when teaching your class? }\end{array}$ & Mean & Mean & $\begin{array}{c}\text { Change } \\
\text { between } \\
\text { P1\& P2 }\end{array}$ & Mean & $\begin{array}{c}\text { Change } \\
\text { between } \\
\text { P1\& P2 }\end{array}$ \\
\hline 1. paper-based materials & 3.3 & 1.8 & -1.5 & 3.0 & +1.2 \\
1. Audio/Video materials & 3.7 & 3.7 & 0 & 3.8 & +0.2 \\
2. Robots & 1.0 & 1.2 & -0.2 & 1.3 & +0.1 \\
3. Manipulation in an experimental lab & 2.2 & 1.3 & -0.9 & 2.2 & +0.9 \\
4. STEM-specific software (e.g., geogebra, & 1.5 & 1.8 & -0.3 & 1.5 & -0.3 \\
$\quad$ function plotter, etc.) & 3.5 & 3.2 & +0.3 & 3.7 & +0.5 \\
5. Word processors & 1.7 & 2.0 & -0.2 & 3.5 & +1.5 \\
6. Online collaborative tools (e.g., padlet, & & 2.5 & -0.2 & 3.2 & +0.7 \\
$\quad$ Google Jamboard, popplet) & 2.7 & 2.5 & & & \\
7. Manipulatives (e.g., base-10, pattern & & 2.2 & -0.2 & 2.8 & +0.6 \\
\hline blocks, virtual manipulatives) & 2.4 & &
\end{tabular}

\section{Overall Changes Over 3 Phases by Teachers}

This section summarizes the overall changes in STEM pedagogical approaches, pedagogical practices, and the use of technological tools across six individual teachers. Of these three categories, ERT greatly impacted teachers' pedagogical practices strategies (average change is -0.5) even though the difference was pretty similar among pedagogical approaches, pedagogical practices, and the use of technological tools. When the instruction was shifted to in-person/hybrid mode, the change in pedagogical approach was considerable. According to the analysis, Judy (pseudonym) seemed to experience the most significant impact by ERT (see Table 6).

TABLE 6 SIX TEACHERS SELF-REPORTED CHANGES OVER 3 PHASES

\begin{tabular}{|c|c|c|c|c|c|c|}
\hline & \multirow{2}{*}{$\begin{array}{c}\text { Phase } 1 \\
\text { Jan-Mar 12, } 2020 \\
\text { Mean }\end{array}$} & \multicolumn{2}{|c|}{$\begin{array}{c}\text { Phase } 2 \\
\text { Mar 13-May } 2020\end{array}$} & \multicolumn{2}{|c|}{$\begin{array}{c}\text { Phase } 3 \\
\text { Oct-Nov } 2020\end{array}$} \\
\hline & & & Mean & $\begin{array}{l}\text { (Change } \\
\text { between } \\
\text { P1 \& P2) } \\
\end{array}$ & Mean & $\begin{array}{l}\text { (Change } \\
\text { between } \\
\text { P2\&P3) }\end{array}$ \\
\hline \multirow{6}{*}{$\begin{array}{l}\text { Q7: Frequency of } \\
\text { STEM pedagogical } \\
\text { approaches }\end{array}$} & Ashley & 2.8 & 2.4 & $(-0.4)$ & 3.1 & $(+0.7)$ \\
\hline & Emma & 2.2 & 1.6 & $(-0.6)$ & 2.6 & $(+1.0)$ \\
\hline & Jessica & 2.5 & 1.9 & $(-0.6)$ & 2.7 & $(+0.8)$ \\
\hline & Judy* & 2.7 & 1.6 & $(-1.1)$ & 3.0 & $(+1.4)$ \\
\hline & Lauren & 2.1 & 2.1 & (0) & 1.8 & $(-0.3)$ \\
\hline & Francis & 3.3 & 3.4 & $(+0.1)$ & 3.0 & $(-0.4)$ \\
\hline
\end{tabular}




\begin{tabular}{l|l|r|rr|rr}
\hline Average of Change & & & & -0.4 & & 0.7 \\
\hline Q8: Pedagogical & Ashley & 3.3 & 2.5 & $(-0.8)$ & 3.6 & $(+1.1)$ \\
practices & Emma & 2.6 & 2.0 & $(-0.6)$ & 2.8 & $(+0.8)$ \\
& Jessica & 2.8 & 1.9 & $(-1)$ & 2.4 & $(+0.5)$ \\
& Judy* & 3.0 & 1.9 & $(-1.1)$ & 3.1 & $(+1.2)$ \\
& Lauren & 2.9 & 2.8 & $(-0.1)$ & 2.1 & $(-0.7)$ \\
& Francis & 2.8 & 3.3 & $(+0.5)$ & 3.0 & $(-0.3)$ \\
\hline Average of Change & & & & -0.5 & & 0.4 \\
\hline Q9: Use of & Ashley & 2.8 & 2.4 & $(-0.4)$ & 3.4 & $(+1)$ \\
technological tools in & Emma & 2.3 & 1.8 & $(-0.5)$ & 2.5 & $(+0.7)$ \\
STEM instruction & Jessica & 2.4 & 1.8 & $(-0.6)$ & 2.8 & $(+1.0)$ \\
& Judy* & 2.3 & 1.6 & $(-0.7)$ & 2.6 & $(+1.0)$ \\
& Lauren & 2.8 & 2.8 & $(0)$ & 2.9 & $(+0.1)$ \\
& Francis & 2.3 & 2.9 & $(+0.6)$ & 2.5 & $(-0.4)$ \\
\hline Average of Change & & & & -0.3 & & 0.6 \\
\hline
\end{tabular}

\section{DISCUSSION AND IMPLICATIONS}

Drawing on the TPACK framework, this study analyzed six elementary teachers' STEM pedagogy in K-5 classrooms and how ERT impacted their teaching pedagogy. The findings of this study propose several implications to the field of STEM education.

First, our findings suggest that ERT impacted the alignment of STEM standards in the classroom, especially with cooperative learning and peer teaching. ERT conditions (e.g., social distancing, online learning) during the pandemic could possibly explain the lack of collaboration and interaction among students in the classroom. Yet, regardless of ERT, Colorado's STEM Standards and Instruction (2020) addresses that collaboration is one of the core pedagogies in STEM classrooms to be met. Also, scientific investigations through questioning, design, data, conclusions, and justification should be incorporated in all strands of STEM teaching and learning. Additionally, this supports students' ability to visually represent mathematics and science concepts, select appropriate tools strategically, and justify their answers by constructing viable arguments, all of which support student engagement. Therefore, the lack of cooperative learning and peer teaching during ERT could strongly impact students' ability to learn STEM standards during ERT.

Second, the survey's self-reported results highlight the teachers' struggle to use technological tools to guide their STEM instruction even before ERT. Through the TPACK lens, there seems to be a shortfall in a teacher's knowledge to integrate new technologies into the curriculum. For instance, with a maximum score of 4 indicating using a technological tool "a lot," teachers reported using robots at 1.0 (not at all), STEM-specific software (e.g., GeoGebra, function plotter, etc.) at 1.5 ("a little bit"), and online collaboration tools (e.g., Padlet, Google Jamboard, Popplet) at 1.7 ("a little bit"), and the manipulation at the experimental lab at 2.2. ("to some extent").

A similar pattern was observed across all six teachers regardless of their school district, years of teaching, school type, or school setting. Among the six respondents, four teachers have more than 11 years of teaching experience, and two teachers were first-year teachers in a K-5 public school. The teachers represent urban, suburban, and rural school populations, and one of them works at a Title- $1^{1}$ school. They teach STEM lessons ranging from 1-5 times per week, and they use computers daily. The district STEM training was mandatory for two first-year teachers but not mandatory for the experienced teachers. Koehler et al. (2014) addressed TPACK as dependent on the schools' context, but our data shows the TPACK of participating teachers doesn't seem strong regardless of a teacher's background.

It was not the intention of this study to highlight teachers' lack of TPACK. However, the findings show that up-to-date technological tools were not the core of STEM instruction even before ERT. This research brings critical attention to teacher training programs, especially from a TPACK and STEM standards 
perspective. Teachers need to have a deep understanding of every aspect of TPACK to orchestrate and coordinate technology into their teaching practices. Do we provide effective teacher training or course works to both pre- and in-service teachers in alignment with the TPACK framework and STEM standards? This question becomes more essential as technology and remote learning have become ubiquitous.

Third, referring to our second research question about STEM teaching during ERT, the comparative analysis of the three phases illustrates a general trend across all three survey questions; the frequency of STEM pedagogical approaches, pedagogical practice, and the use of technological tools all decreased during Phase 2 when in-person instruction shifted to ERT. Yet, these practices re-appeared when in-person instruction was delivered to some extent during Phase 3, but it was not as often as Phase 1. For instance, in terms of pedagogical knowledge practice, ERT during Phase 2 brought an extensive drop in students' group work (from 3.2 to 1.8), and an increased students' individual work at their own pace (from 2.3 to 3.3.) Teachers reported that they conducted more group work during Phase 3 (from 1.8 to 2.7) and reduced students' individual work (from 3.3 to 2.8) when the instruction was back to in-person to some degree. However, compared to Phase 1, when in-person instruction typically occurred, students' collaboration during Phase 3 remained lower than Phase 1 (2.7 during Phase 3 vs. 3.2 during Phase 1) and student's individual learning practice during Phase 3 was higher than Phase 1 ( 2.8 during Phase 3 vs. 2.3 during Phase 1) One interesting finding was about the adaptation of traditional direct instruction during the pandemic. We assumed that direct instruction would increase during ERT and Phase 3 because it would be more readily applicable than interactive instruction in a virtual classroom. However, our findings show that direct instruction decreased during Phases 2 and 3 (from 3.2 to 2.5) and remained the same during Phase 3. Another noticeable finding came from the adaptation of teachers' integration of online collaborative tools in their instruction. At first, teachers reported that they used online collaborative tools a little bit (1.7 out of 4), but it increased in Phase 2 (2.0) and increased largely in Phase 3 (3.5, a lot category). Although the pedagogical practice of students' group work and collaborative work physically decreased significantly during Phase 2, ERT provided teachers with the experience of TPACK to learn how to utilize online tools to promote collaboration and interactive learning for their students. Thus, this experience eventually led teachers to implement more collaboration and interactive learning within their STEM instruction during Phase 3. This finding could explain how we can better support teachers to align critical STEM pedagogies in virtual classrooms.

\section{Recommendations for Future Research}

This study investigated six elementary teachers' change of practices in STEM pedagogy during the pandemic. Still, open questions remain in other areas such as STEM instructions in middle school or high schools, schools that are already doing virtual learning, or schools in different settings like homeschooling, etc. Also, there is a need to broaden the research scope with more teachers from various school and district settings. It would also be beneficial to look at the relationships between STEM standards alignment in a classroom and the teacher training opportunities in the district or institution. This study collected data during a specific time of the year considering the unique situation of the pandemic. Still, it is recommended to collect data for the whole academic year or more extended time to have a better snapshot of STEM educational practices. Also, adding a qualitative perspective via in-depth interviews with teachers will add another layer providing profound insight into STEM education.

\section{ENDNOTE}

1. Title 1 is a federal aid program for the schools. According to the Title 1 (Part A), Elementary and Secondary Education Act, "the government provides financial assistance to local educational agencies (LEAs) and schools with high numbers or high percentages of children from low-income families to help ensure that all children meet challenging state academic standards". US Department of Education. https://www2.ed.gov/programs/titleiparta/index.html 


\section{REFERENCES}

Bartholomew, S.R., Strimel, G.J., Zhang, L., \& Homan, J. (2018). Examining the potential of adaptive comparative judgement for elementary STEM design assessment. The Journal of Technology Studies, 44(2), 58-75.

Baxter, J.A., Woodward, J., \& Olson, D. (2001). Effects of reform-based mathematics instruction on low achievers in five third-grade classrooms. The Elementary School Journal, 101(5), 529-547.

Black, E., Ferdig, R., \& Thompson, L.A. (2021). K-12 virtual schooling, COVID-19, and student Success. JAMA Pediatrics, 175(2), 119-120. https://doi.org/10.1001/jamaperdiatrics.2020.3800

Bloomberg, L.D., \& Volpe, M. (2016). Completing Your Qualitative Dissertation A Road Map From Beginning to End (Third). Sage.

Breiner, J.M., Harkness, S.S., Johnson, C.C., \& Koehler, C.M. (2012). What is STEM? A discussion about conceptions of STEM in education and partnerships. School Science and Mathematics, $112(1), 3-11$.

Cahapay, M.B. (2020). Rethinking Education in the New Normal Post-COVID-19 Era: A Curriculum Studies Perspective. Aquademia, 4(2), ep20018. https://doi.org/10.29333/aquademia/8315

Cavanaugh, C., \& DeWeese, A. (2020). Understanding the professional learning and support needs of educators during the initial weeks of pandemic school closures through search terms and content use. Journal of Technology and Teacher Education, 28(2), 233-238.

Centers for Disease Control and Prevention. (2020). Operating Schools During COVID-19. Retrieved from https://www.cdc.gov/coronavirus/2019-ncov/community/schools-childcare/schools.html

Code, J., Ralph, R., \& Forde, K. (2020), Pandemic designs for the future: Perspectives of technology education teachers during COVID-19. Information and Learning Sciences, 121(5/6), 419-431. doi.10.1108/ILS-04-2020-0112

Dare, E.A., Ring-Whalen, E.A., \& Roehrig, G.H. (2019). Creating a continuum of STEM models: Exploring how K-12 science teachers conceptualize STEM education. International Journal of Science Education, 41(12), 1701-1720. doi:10.1080/09500693.2019.1638531

English, L.D. (2016). STEM education K-12: Perspectives on integration. International Journal of STEM Education, 3(1), 1-8. doi:10.1186/s40594-016-0036-1

Freire, P. (1998). Pedagogy of freedom: Ethics, democracy, and civic courage. Rowman \& Littlefield Publishers.

Hodges, C., Moore, S., Lockee, B., Trust, T., \& Bond, A. (2020, March 27). The difference between emergency remote teaching and online learning. Educause Review.

Holmlund, T.D., Lesseig, K., \& Slavit, D. (2018). Making sense of "STEM education" in K-12 contexts. International Journal of STEM Education, 5(1), 32. doi:10.1186/s40594-018-0127-2

Honey, M., Pearson, G., \& Schweingruber, H. (Eds.). (2014). STEM integration in K-12 education: Status, prospects, and an agenda for research. National Academies Press.

Hwang, G.J., \& Lai, C.L. (2017). Facilitating and bridging out-of-class and in-class learning: An interactive E-book-based flipped learning approach for math courses. Educational Technology \& Society, 20(1), 187-197.

Kelley, T.R., \& Knowles, J.G. (2016). A conceptual framework for integrated STEM education. International Journal of STEM Education, 3(11), 2-11.

Koehler, M.J., \& Mishra, P. (2009). What is technological pedagogical content knowledge? Contemporary Issues in Technology and Teacher Education (CITE), 9(1), 60-70.

Koehler, M.J., Greenhalgh, S., Rosenberg, J., \& Keenan, S. (2017). What the tech is going on with teachers' digital teaching portfolios? Using the TPACK framework to analyze teachers' technological understanding. Journal of Technology and Teacher Education, 25(1), 31-59.

Koehler, M.J., Mishra, P., Kereluik, K., Shin, T.S., \& Graham, C.R. (2014). The technological pedagogical content knowledge framework. In J.M. Specter, M.D. Merrill, J. Elen, \& M.J. Bishop (Eds.), Handbook of research on educational communications and technology (pp. 101-111). Springer. 
Koehler, M.J., Shin, T.S., \& Mishra, P. (2012). How do we measure TPACK? Let me count the ways. In R.N. Ronau, C.R. Rakes, \& M.L. Niess (Eds.), Educational technology, teacher knowledge, and classroom impact: A research handbook on frameworks and approaches (pp. 16-31). IGI Global.

Korkmaz, G., \& Toraman, Ç. (2020). Are we ready for the post-COVID-19 educational practice? An investigation into what educators think as to online learning. International Journal of Technology in Education and Science (IJTES), 4(4), 293-309.

Liang, L.L., \& Richardson, G.M. (2009). Journal of Elementary Science Education, 21(1), 51-66.

Marshall, D.T., Shannon, D.M., \& Love, S.M. (2020, September 2). How teachers experienced the COVID-19 transition to remote instruction. Phi Delta Kappan.

Means, B., Bakia, M., \& Murphy, R. (2014). Learning online: What research tells us about whether, when and how. Routledge.

Milman, N.B. (2020, March 25). Pandemic pedagogy. Phi Delta Kappan.

Mishra, P., \& Koehler, M.J. (2006). Technological pedagogical content knowledge: A framework for teacher knowledge. Teachers College Record, 108(6), 1017-1054. doi: 10.1111/j.14679620.2006.00684.x

Nadelson, L.S., \& Seifert, A.L. (2017). Integrated STEM defined: Contexts, challenges, and the future. Journal of Educational Research, 110(3), 221-223. https://doi.org/10.1080/00220671.2017.1289775

National Council of Teachers of Mathematics. (2000). Principles and standards for school mathematics. Reston, VA: NCTM.

Nistor, A., Gras-Velazquez, A., Billon, N., \& Mihai, G. (2018). Science, technology, engineering and mathematics education practices in Europe. Scientix Observatory Report. Retrieved from http://www.scientix.eu/observatory/stem-education-practices-europe

NRC. (2000). Inquiry and the National Science Education Standards. Washington, DC: National Academy Press.

Plonczak, I., Joseph, R., \& Stemn, B. (2010). Videoconferencing in math and science preservice elementary teachers' field placement. Journal of Science Teacher Education, 21(2), 241-254.

Riordan, J.E., \& Noyce, P.E. (2001). The impact of two standards-based mathematics curricula on student achievement in Massachusetts. Journal for Research in Mathematics Education, 32(4), 368-398.

Santanu, D. (2020). Impacts of the COVID-19 Pandemic on Global Education. Royal Book Publishing. doi:10.26524/royal.37.6

Satchwell, R.E., \& Loepp, F. K. (2002). Designing and implementing an integrated mathematics, science, and technology curriculum for the middle school. Journal of Industrial Teacher Education, 39(3), 41-66.

Schmidt, M., \& Fulton, L. (2016). Transforming a traditional inquiry-based science unit into a STEM unit for elementary pre-service teachers: A view from the trenches. Journal of Science Education and Technology, 25(2), 302-315.

Shulman, L. (1987). Knowledge and teaching: Foundations of the new reform. Harvard Educational Review, 57(1), 1-23.

Trust, T., \& Whalen, J. (2020). Should teachers be trained in emergency remote teaching? Lessons learned from the COVID-19 pandemic. Journal of Technology and Teacher Education, 28(2), 189.

Tsupros, N., Kohler, R., \& Hallinen, J. (2009). STEM education: A project to identify the missing components. Intermediate Unit 1: Center for STEM Education and Leonard Gelfand Center for Service Learning and Outreach. Carnegie Mellon University.

Van Nuland, S.E., Hall, E., \& Langley, N.R. (2020). STEM crisis teaching: Curriculum design with elearning tools. FASEB BioAdvances, 2, 631-637. https://doi.org/10.1096/fba.2020-00049

Wood, T. (1993). Creating an environment for learning mathematics: Social interaction perspective. Elementary School Mathematics: Insights and Issues, pp. 15-20+115-122.

Yin, R.K. (2009). Case study research design and methods. Los Angeles, CA: Sage 
Zulirfan, Z., Yennita, Y., \& Rahmad, M. (2020). STEM at home: Provide scientific activities for students during the covid-19 pandemic. Journal of Physics, Conference Series, 1655(1).

https://doi.org/10.1088/1742-6596/1655/1/012068

\section{APPENDIX}

FIGURE 1

CHANGES OF STEM PEDAGOGICAL APPROACHES OVER 3 PHASES

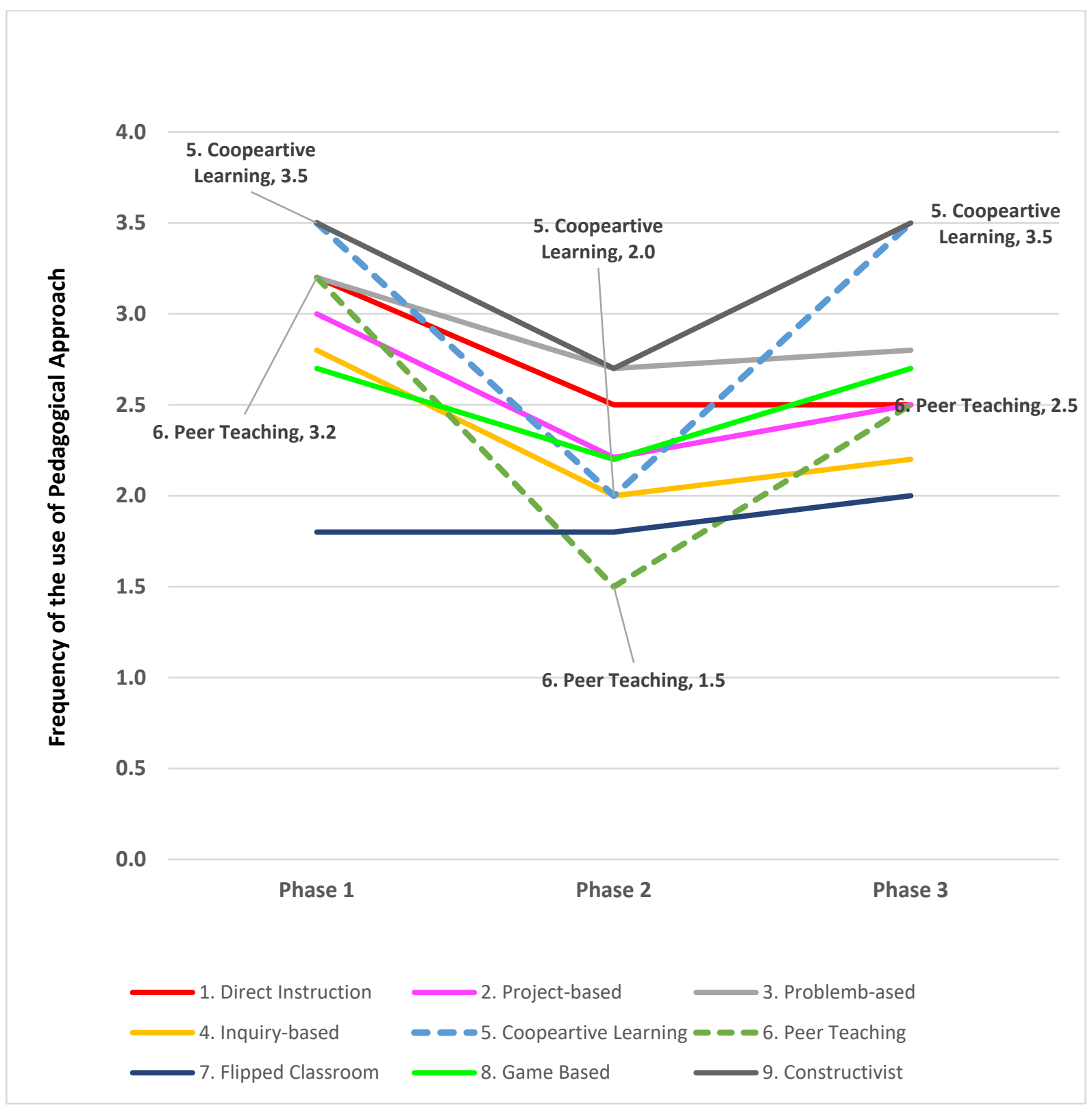

